\title{
Rola mniejszości narodowych w kulturze i oświacie polskiej w latach 1700-1939, pod red. Aleksandry Bilewicz i Stefanii Walasek, Wydawnictwo Uniwersytetu Wroclawskiego, Wroclaw 1998, s. 380
}

Pobieżny chociażby przegląd większości dzisiejszych (i nie tylko) konfliktów światowych wskazuje jasno genezę powstawania wszelkich ognisk zapalnych na naszym globie: jest nią brak tolerancji dla czegoś innego, obawa przed ,obcym - nieznajomym". Przykładowy los uchodźców kurdyjskich czy albańskich pokazuje, iż to najczęściej mniejszości narodowe padają ofiarą owego braku zrozumienia i wciąż narastających nastrojów zbyt doslownie pojmowanego nacjonalizmu. Źródlem tych nieporozumień jest brak dostatecznej wiedzy $o$ innych narodach $i$ zbytnie egzaltowanie się własną historią i tradycją.

Cenną zatem wydaje się być publikacja Wydawnictwa Uniwersytetu Wrocławskiego poświęcona właśnie znaczeniu i roli mniejszości narodowych w kulturze i oświacie polskiej w latach 1700-1939. Cenną, ponieważ właśnie państwo polskie w omawianym okresie swoich dziejów było klasycznym przykładem kraju o bogatej mozaice narodowościowej, cenną, bo pokazująca obraz niejednokrotnie pozytywnych relacji między mniejszościami. Relacje te były często pomocne w tworzeniu własnych tożsamości narodowych.

Omawiany tom stanowi zbiór artykułów-referatów wygłoszonych na Międzynarodowej Konferencji Naukowej, zorganizowanej przez Zakład Historii Oświaty i Wychowania Uniwersytetu Wrocławskiego, która odbyła się we Wrocławiu 10-11 października 1996 r. Wybór miejsca tej konferencji też wydaje się nie być przypadkowy, wszak to właśnie Wrocław po II wojnie światowej stał się tyglem, gdzie spotkali się również przedstawiciele wszystkich mniejszości narodowych, zamieszkujących tereny II Rzeczypospolitej.

Mimo, iż w tytule pracy podkreślono dość szeroki zakres czasowy problemu, większość artykułów dotyczy XX wieku, a jeszcze ściślej okresu międzywojennego. Podobna wybiórczość widoczna jest także w opisie najliczniejszych mniejszości wyznaniowych i narodowych, zamieszkujących kiedykolwiek ziemie polskie: Żydów, Niemców i Ukraińców. Jedynie dwa referaty poświęcono mniejszości ormiańskiej. Prace w publikowanym tomie uporządkowano wg klucza chronologicznego, zawartego już w tytule.

Tom rozpoczyna artykuł L. Mokrzeckiego, który dotyczy znaczenia mniejszości narodowych w Prusach Królewskich (na przykładzie uczonych i środowiska patrycjatu w XVIII wieku). Kolejne dwie publikacje dotyczą Ormian: opisuja ich miejsce i rolę w Kościele rzymskokatolickim w XVIII wieku (B. Rok) i ich postawę wobec śmierci w świetle lwowskich testamentów przez nich spisywanych (F. Wolański). Dalej R. Stępień omawia wkład bazylianów (zakonników w Kościele unickim) w kulturę i oświatę polską na terenie Korony Polskiej i Wielkiego Księstwa Litewskiego w drugiej połowie XVIII wieku. Następny autor tomu - B. Krawiec - przedstawia rolę nauczycieli-cudzoziemców, pracujących na Uniwersytecie Charkowskim w początkach jego działalności, tj. w latach 1805-1820. Kolejne cztery artykuły dotyczą mniejszości narodowych, zamieszkujących zabór austriacki: W. Jamrożek pokazuje stanowisko polskiej socjalnej demokracji wobec dążeń oświatowych Ukraińców w Galicji, A. Meissner - udział ukraińskich nauczycieli $w$ życiu społecznym Galicji (na przykładzie kadry pedagogicznej zatrudnionej w seminariach nauczycielskich), A. Ladyżyński omawia miejsce i znaczenie cudzoziemców oraz przedstawicieli mniejszości w szkołach zawodowych Galicji w dobie autonomii, K. Rędziński zaś skupia się na żydowskich fundacjach oświatowych w Galicji z przełomu wieków. Problemem oświaty 
mniejszości żydowskiej zajmują się także teksty autorstwa: J. Hellwiga (Edukacja mlodzieży żydowskiej w XIX w. w Poznaniu), R. Kuchy (Zydzi lubelscy w walce z rusyfikacjq mlodzieży w latach 1864 -1915) i J. Suchmiel (Kariery naukowe Żydówek na Uniwersytecie Jagiellońskim do czasów Drugiej Rzeczypospolitej. Komunikat $z$ badań).

XIX wieku dotyczy jeszcze jedna praca - A. Winiarza, która przedstawia udział mniejszości niemieckiej w życiu kulturalno-oświatowym Księstwa Warszawskiego i Królestwa Polskiego w latach 1807-1915. „Pomostem”, łączącym XIX i XX wiek jest $\mathrm{z}$ kolei artykuł E. Witkowskiej. Pokazuje on bowiem stosunek mniejszości narodowych wobec rozwoju szkolnictwa w Lodzi w XIX i XX wieku (do 1939 roku).

Kolejne prace chronologicznie przynależą już do czasów Drugiej Rzeczypospolitej. Wstępem do tej części tomu jest referat R. Stankiewicza, który omawia prawne podstawy działalności szkolnictwa dla mniejszości narodowych w zaznaczonym już okresie. Następni autorzy przedstawiają stanowisko wybranych partii i obozów politycznych wobec problemu mniejszościowego. W. Wojdyło omawia stosunek obozu narodowo-demokratycznego, a M. Strzelecki - ruchu ludowego, do idei pluralizmu kulturalnego. K. Jakubiak pisze natomiast o problemie mniejszości narodowych w piłsudczykowskim programie politycznym i doktrynie wychowania państwowego. Kolejne artykuly poruszaja następujące problemy: Mniejszości narodowe wśród studentów szkól wyższych II RP (B. Ratuś), Problem mniejszosci narodowych $w$ jędrzejewiczowskiej reformie programu historii dla szkól powszechnych (E. Magiera) i Formy opieki nad dzieckiem $w$ lódzkich mniejszosciach narodowych (1918-1939) (T. Jałmużna, N. Stolińska).

W okresie Drugiej Rzeczypospolitej powraca także problem mniejszości żydowskiej. Zajęly się nim kolejno: R. Renz, pisząca o wychowaniu w rodzinie żydowskiej, M. Meducka, zajmująca się bibliotekami żydowskimi, D. Kożmian, która przedstawiła podręczniki szkolne polskich Żydów, H. Raczek, która pokazała działalność oświatową społeczności żydowskiej na Lubelszczyźnie i M. Balukiewicz, badająca działalność Towarzystwa dla Opieki nad Żydowskimi Sierotami we Lwowie w latach 1916-1939. Kwestię mniejszości niemieckiej w okresie międzywojennym poruszył L. Smołka w artykule pt.: Szkola mniejszościowa czy dwujęzyczna państwowa. Ślqsk Opolski w latach 1922 - 1939. W sprawie używania politonimów zamiast etnonimów na przykładzie prac biograficznych wypowiedział się natomiast W. Hryckiewicz (opisując przypadek mniejszości białoruskiej).

Omawianą publikacje kończą wystąpienia gości zagranicznych, nie związane zbytnio $\mathrm{z}$ tematem konferencji. J. Pšenảk opisuje gimnazja słowackie i ich wpływ na rozwój tożsamości narodowej, I. Swarnyk skupia się na oświacie ukraińskiej w Galicji Wschodniej przed rokiem 1939, a T.M. Smirnowa przedstawia szkoły dla mniejszości narodowych $w$ Piotrogrodzie-Leningradzie w latach 1918-1938. Dwa ostatnie artykuły pokazują rolę i miejsce szkolnictwa polskiego na Lotwie (E. Jekabson, S. Walasek). Wystąpienia te, co redaktorki tomu zaznaczyły we wstępie, oparte były na mało dostępnych dla polskich badaczy źródłach, stąd wynika ich wartość i miejsce właśnie w tym tomie. Pokazały ponadto „problemy mniejszości widziane przez przedstawicieli innych narodów, uświadamiały fakt, że dorobek kulturalny poszczególnych narodów zamieszkujących różne regiony wchodzi w skład wspólnej kultury europejskiej" (s. 5). Slowa te nabierają specjalnego znaczenia dziś, gdy wiele krajów pretenduje do miana państw demokratycznych, zapominając przy tym, iż „miarą stopnia cywilizacji kraju i stanu jego demokracji jest [wlaśnie - E.G.] stosunek do mniejszości narodowych" (s. 181).

Edyta Glowacka 